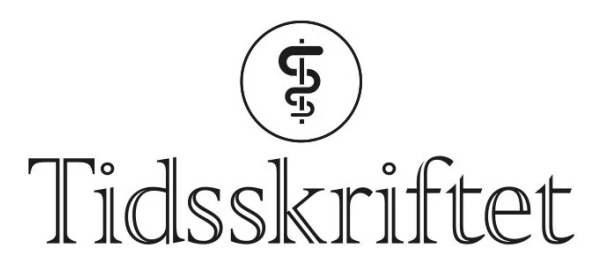

DEN NORSKE LEGEFORENING

\title{
Behandling med statiner
}

\author{
LEGEMIDLER I PRAKSIS
}

\section{MARTIN PRØVEN BOGSRUD}

Martin Prøven Bogsrud (f. 1981) er lege i spesialisering.

Forfatter har fylt ut ICMJE-skjemaet og oppgir ingen interessekonflikter.

Lipidklinikken

Avdeling for forebyggende medisin

Medisinsk klinikk

Oslo universitetssykehus, Rikshospitalet

og

Medisinsk avdeling - Ålesund

Helse Møre og Romsdal

\section{ÅSMUND REIKVAM}

Åsmund Reikvam (f. 1944) er spesialist i hjertesykdommer og professor. Forfatter har fylt ut ICMJE-skjemaet og oppgir ingen interessekonflikter. Farmakologisk institutt Institutt for klinisk medisin Det medisinsk fakultet Universitetet i Oslo og

Avdeling for farmakologi Oslo universitetssykehus

\section{KJETIL RETTERSTØL}

Kjetil Retterstøl (f. 1962) er spesialist i medisinsk biokjemi, overlege og førsteamanuensis.

Forfatter har fylt ut ICMJE-skjemaet og oppgir følgende interessekonflikter: Han har mottatt honorar fra Mills DA og MSD for vitenskapelige råd samt foredragshonorar fra Abbott, Roche, AstraZeneca og Novartis.

Email: kjetil.retterstol@medisin.uio.no

Lipidklinikken

Avdeling for forebyggende medisin

Medisinsk klinikk

Oslo universitetssykehus, Rikshospitalet

og

Avdeling for ernæringsvitenskap

Institutt for medisinsk basalfag

Medisinsk fakultet

Universitetet i Oslo

For 21 år siden ble det første statinet registrert i Norge. Nå er statiner blant våre best dokumenterte og mest brukte legemidler. En av fem personer over 40 år brukte statiner $\mathrm{i}$ 


\section{Norge i 2011. I denne artikkelen oppsummeres indikasjoner og praktiske råd ved statinbehandling.}

Statiner er en klassebetegnelse på medikamenter som hemmer det hastighetsbegrensende enzymet (HMG-CoA-reduktase) i cellenes kolesterolsyntese (fig 1). Dette fører til oppregulering av low density lipoprotein (LDL)-reseptorer på celleoverflatene og økt clearance av sirkulerende LDL-kolesterol fra blodet. De første statinene ble i 1978 oppdaget som naturlige gjæringsprodukter fra sopp (11). I dag er seks statiner tilgjengelig på det norske markedet (tab 1). Totalt 488678 personer fikk i 2011 utlevert minst én resept på statin i Norge (2).

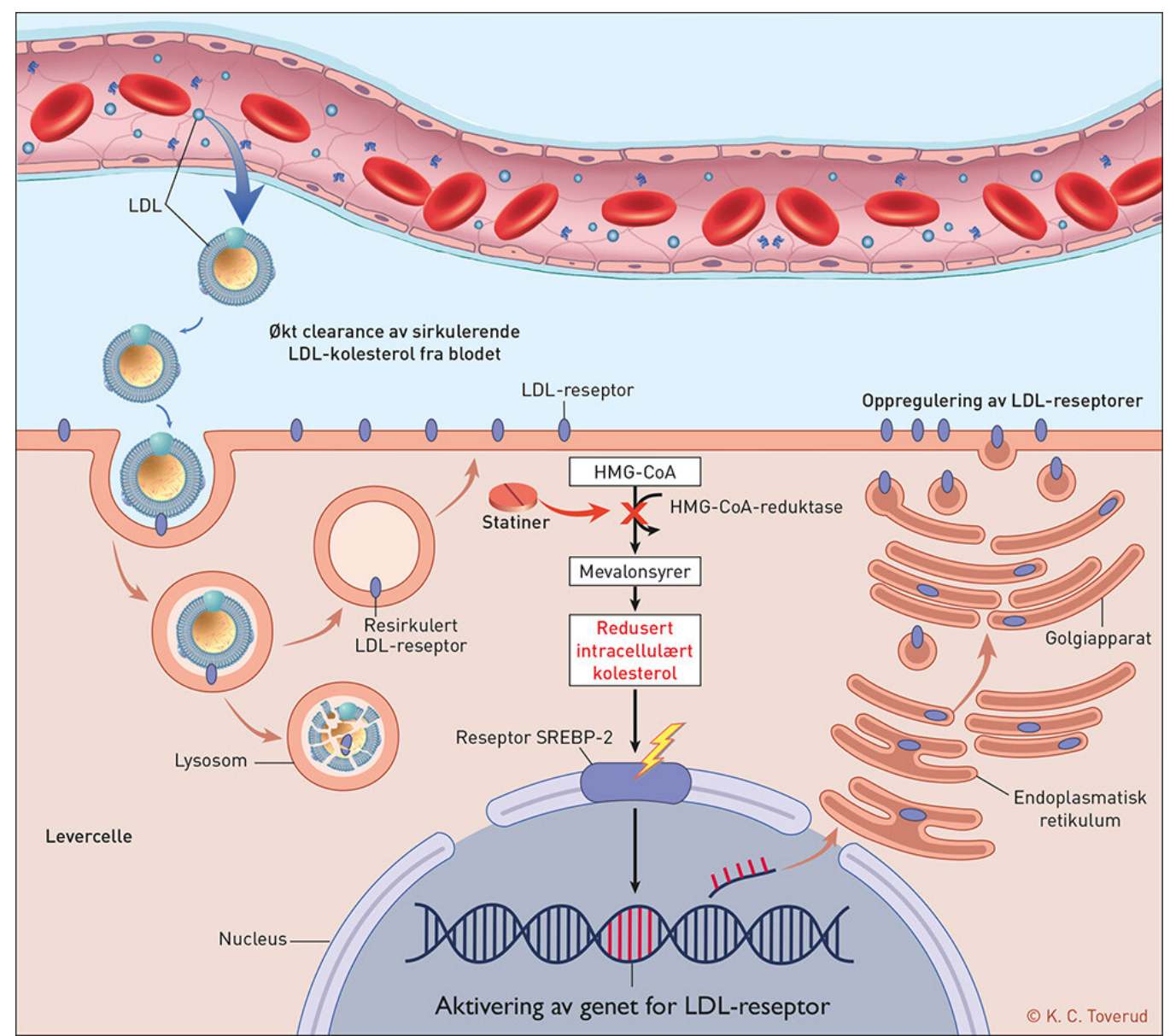

Figur 1 Den kolesterolsenkende virkningen av statiner foregår i levercellene. Statiner hemmer det hastighetsbegrensende enzymet i kolesterolsyntesen (HMG-CoA-reduktase) og gir redusert kolesterol intracellulært. Dette akiverer transkripsjonsfaktoren SREBP-2 slik at LDL-reseptorgenet øker produksjonen av LDL-reseptorer som festes til celleoverflaten. Dette gir økt kolesterolopptak til levercellen, og den intracellulære kolesterolkonsentrasjonen holdes i balanse mens nivået av sirkulerende LDL-kolesterol faller

\section{Tabell 1}

De vanligste statinene med anbefalt dose og doseringstidspunkt samt oversikt over de faktorene som hyppigst gir $ø$ kt risiko for bivirkninger (11)

\begin{tabular}{|c|c|c|c|}
\hline Substansnavn & $\operatorname{Doser}(\mathbf{m g})$ & Dosering & $\begin{array}{l}\text { Medikamenter og andre faktorer som øker } \\
\text { bivirkningsrisiko }\end{array}$ \\
\hline
\end{tabular}




\begin{tabular}{|c|c|c|c|}
\hline Substansnavn & Doser (mg) & Dosering & $\begin{array}{l}\text { Medikamenter og andre faktorer som øker } \\
\text { bivirkningsrisiko }\end{array}$ \\
\hline \multirow{6}{*}{ Simvastatin } & \multirow{6}{*}{$10-80$} & \multirow{6}{*}{ Kveld } & Kontraindisert ved bruk av: \\
\hline & & & $\begin{array}{l}\text { Makrolidantibiotika, hiv-proteasehemmere, } \\
\text { ciklosporin, danazol, itrakonazol, ketokonazol, } \\
\text { posakonazol, gemfibrozil }\end{array}$ \\
\hline & & & Forsiktig dosering ved samtidig bruk av: \\
\hline & & & Diltiazem, verapamil, amiodaron, amlodipin \\
\hline & & & Unngå inntak av: \\
\hline & & & Grapefruktjuice $>0,5 \mathrm{l} / \mathrm{dag}$ eller johannesurt \\
\hline Lovastatin & $20-40$ & Kveld & Samme som for simvastatin \\
\hline \multirow[b]{2}{*}{ Atorvastatin } & \multirow[b]{2}{*}{$10-80$} & \multirow[b]{2}{*}{ Når som helst } & Forsiktig dosering ved samtidig bruk av: \\
\hline & & & $\begin{array}{l}\text { Ciclosporin, itrakonazol, ketokonazol, } \\
\text { posakonazol, makrolidantibiotika, diltiazem, } \\
\text { verapamil og flukonazol, hiv- } \\
\text { proteasehemmere, gemfibrozil }\end{array}$ \\
\hline \multirow{2}{*}{ Pravastatin } & \multirow{2}{*}{$20-40$} & \multirow{2}{*}{ Kveld } & Forsiktig dosering ved samtidig bruk av: \\
\hline & & & Ciklosporin \\
\hline \multirow{2}{*}{ Fluvastatin } & \multirow{2}{*}{$20-80$} & \multirow{2}{*}{ Kveld } & Forsiktig dosering ved samtidig bruk av: \\
\hline & & & Flukonazol \\
\hline \multirow[b]{2}{*}{ Rosuvastatin } & \multirow[b]{2}{*}{$5-40$} & \multirow[b]{2}{*}{ Når som helst } & Forsiktig dosering ved samtidig bruk av: \\
\hline & & & $\begin{array}{l}\text { Ciklosporin, hiv-proteasehemmere, } \\
\text { gemfibrozil. Asiatiske pasienter bør få lav } \\
\text { dose }\end{array}$ \\
\hline
\end{tabular}

En rekke kontrollerte studier har vist redusert risiko for kardiovaskulær sykdom og død hos personer som behandles med statiner. Dette gjelder både personer med og uten aterosklerotisk sykdom samt med og uten høyt kolesterol. En metaanalyse av kliniske studier har vist at risiko for kardiovaskulær sykdom minskes med en femdel for hver 1,o mmol/l LDL-kolesterol som reduseres. Det er ikke påvist noen nedre terskelverdi for effekt knyttet til LDL-kolesterolsenkningen (3).

Gjennomgangen under baserer seg på egen litteraturbase, et ikke-systematisk litteratursøk i PubMed samt klinisk erfaring og praksis ved Lipidklinikken, Oslo universitetssykehus, Rikshospitalet.

\section{Indikasjoner og beregning av risiko}

Pasienter med svært høy kardiovaskulær risiko bør bruke statiner. For alle andre personer må legen foreta en individuell risikovurdering. Grupper som er anført å ha svært høy kardiovaskulær risiko i henhold til de europeiske retningslinjene for behandling av dyslipidemi fra 2011 er oppsummert i ramme 1 (4.).

\section{RAMME 1}

Pasienter som har svcert har svcert høy risiko for kardiovaskulcer sykdom (4) og bør bruke statiner

- Pasienter med påvist kardiovaskulær sykdom (sekundærprofylakse) 
- Pasienter med diabetes type 2 og pasienter med diabetes type 1 med

mikrovaskulære komplikasjoner

- Pasienter med redusert nyrefunksjon (GFR $<60 \mathrm{ml} / \mathrm{min} / 1,73 \mathrm{~m}^{2}$ )

- Personer uten sykdommene nevnt i punktene over, men som har ti års kalkulert

risiko for kardiovaskulær $\mathrm{d} ø \mathrm{~d}>10 \%$ (primærprofylakse)

Flere risikokalkulatorer er fritt tilgjengelig på Internett. Helsedirektoratets kalkulator er tilpasset norsk befolkning og beregner ti års risiko for kardiovaskulær død ut fra kjønn, alder, røykestatus, systolisk blodtrykk og totalkolesterol (5). Kalkulatorene har imidlertid noen begrensninger. Noen faktorer medfører høyere risiko enn det kalkulatoren viser (4): høye verdier av triglyserid, lipoprotein (a), homocystein, C-reaktivt protein (CRP) og fibrinogen samt tidlig kardiovaskulær sykdom i familien, depresjon, abdominal fedme, kronisk inflammatorisk sykdom som revmatoid artritt eller psoriasis, og fysisk inaktivitet. Høyt HDL-kolesterol og/eller fravær av kardiovaskulær sykdom i slekten gir lavere risiko enn det kalkulatoren angir. Tidlig kardiovaskulær sykdom hos nære slektninger tillegges mindre vekt dersom årsaken antas å være uheldig livsstil. Den endelige avgjørelsen om oppstart av statinbehandling må til sist baseres på legens kliniske skjønn og pasientens egne preferanser.

\section{Norske retningslinjer}

De norske retningslinjene fra 2009 er etter vår mening gode på primærprofylakse (므). Ti års risiko for kardiovaskulær død øker naturligvis kraftig med alderen. For å korrigere for dette blir risiko i de norske retningslinjene differensiert etter alder: Behandling med statiner kan være aktuelt ved en ti års risiko over $1 \%$ for personer under 50 år, over $5 \%$ for personer i $50-$ 60 årsalderen og over $10 \%$ for personer i alderen $60-70$ år. Personer som har kolesterol over 8,o mmol/l eller familiær hyperkolesterolemi bør også tilbys statinbehandling. Barn med familiær hyperkolesterolemi bør vurderes for statinbehandling fra 10-14 års alder (7.), slik praksis er på Lipidklinikken. Høyt kolesterol fra fødselen av gir en kolesterolbelastning over tid som det ikke tas høyde for i en risikotabell som er laget ut ifra en normalbefolkning.

\section{Statiner til eldre}

For den eldste aldersgruppen er tiårsrisikoen for død høy. Vi har sparsom dokumentasjon for effekten av statiner i spesielle grupper, som svært gamle eller svært unge personer. De norske nasjonale retningslinjene fra 2009 angir at statiner i primærprofylakse sjelden er aktuelt over 75 år. Foreliggende data antyder imidlertid at eldre over $75-80$ år har like god reduksjon i kardiovaskulær risiko som yngre, både i primærprofylakse og i sekundærprofylakse (4). Sykdomsbildet er ofte mer sammensatt hos eldre, som har økt risiko for bivirkninger og for medikamentinteraksjoner. Dette må tas i betraktning ved valg av behandling. Forventet levetid må også vurderes og bør antakelig være mer enn to år for at man skal kunne nyttiggjøre seg statineffekten.

\section{Behandlingsmål}

I de norske retningslinjene for primærforebygging av hjerte- og karsykdommer fra $2009(\underline{6})$. anføres det at totalkolesterolverdier under $5 \mathrm{mmol} / \mathrm{l}$ og LDL-kolesterol under $3 \mathrm{mmol} / \mathrm{l} \mathrm{er}$ tilfredsstillende i primærprofylakse. De europeiske retningslinjene for primærprofylakse 
er strengere. Her anbefales LDL-kolesterol under $3 \mathrm{mmol} / \mathrm{l}$ ved moderat risiko, under 2,5 mmol/l ved høy risiko, og ved svært høy risiko bør verdiene være under 1,8 mmol/l eller LDL-kolesterolet reduseres med minst 50 \% fra utgangsnivået (4.).

\section{Valg og dosering}

Såfremt det oppnås samme LDL-kolesterolreduksjon anses alle statinene likeverdige i forebygging av kardiovaskulær sykdom og død (3). I dag gjelder samme refusjonsvilkår for alle statinene. Unntaket er rosuvastatin som bare har refusjon ved familiær hyperkolesterolemi. Pravastatin og fluvastatin reduserer kolesterolet i mindre grad (ㅁ), men brukes i særlige tilfeller, som for eksempel hos mange organtransplanterte pasienter der man ofte ikke kan bruke andre statiner pga. interaksjoner med immunsuppressiver.

Pasienten kan vanligvis starte med den dosen statin som anses nødvendig. Simvastatin i høyeste dose (8o mg) bør normalt ikke brukes fordi det øker risikoen for bivirkninger (9.),

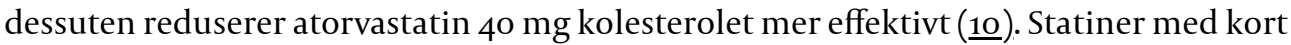
halveringstid (simvastatin, pravastatin, fluvastatin) bør tas om kvelden, da kolesterolproduksjonen i leveren er størst om natten. Statiner med lang halveringstid (atorvastatin og rosuvastatin) kan tas når som helst på dagen.

En rekke medikamenter kan gi økt systemisk eksponering for statin og dermed økt risiko for bivirkninger. De viktigste interaksjonene er vist i tabell 1 (1ㅡ). Statinbehandling kan også gi økte INR-verdier. Bruker pasienten marevan, bør INR derfor monitoreres ved oppstart og doseendring av statin.

\section{Bivirkninger}

I de store statinstudiene er bivirkningsfrekvensen lav (<1\%)( 12$)$. Mangelfulle registreringsrutiner for bivirkninger og strenge inklusjons- og eksklusjonskriterier gjør at det reelle bivirkningsproblemet i klinisk praksis er større enn det som fremgår i kontrollerte studier. Systematiske oversikter og pasient-kontroll-studier antyder at bivirkningsfrekvensen er omtrent $5 \%$, hvorav halvparten er gastrointestinale og halvparten muskulære (13). Selv om statiner vanligvis er godt tolerert, kan et bredt spekter av bivirkninger forekomme, for eksempel leddsmerter, hodepine og tretthet. Stigning i kreatinkinase (CK), aspartataminotransferase (ASAT) og alaninaminotransferase (ALAT) kan forekomme. Lipidklinikken anbefaler monitorering av alle tre, særlig ALAT, før oppstart av behandlingen, ved 6-8 uker etter oppstart og doseendring samt årlig kontroll ved stabil behandling. Statinbehandling ledsages ofte av livsstilsendring, og vår efaring er at kraftig fysisk aktivitet oftest er den naturlige forklaringen på høy CK-verdi. Hard trening bør derfor unngås 2-3 dager før prøvetaking. Rabdomyolyse forekommer hos mindre enn o,1 \% av behandlede pasienter, men medikamentinteraksjoner kan i betydelig grad $\emptyset \mathrm{ke}$ risikoen for denne alvorlige bivirkningen (14.). Statinbehandling gir $\emptyset \mathrm{kt}$ forekomst av diabetes, i størrelsesorden ett nytt tilfelle per 1 ooo pasientår med behandling, men samtidig forebygges ni kardiovaskulære hendelser (15). Bedret overlevelse av statinbehandlede pasienter med risiko for diabetes kan føre til diabetes som «bivirkning».

\section{Tiltak ved bivirkninger}

De fleste bivirkningene forekommer uten biokjemiske avvik, og gastrointestinale plager og muskel-skjelett-plager forekommer hyppig i den generelle befolkningen. Når slike plager oppstår hos en pasient som får statinbehandling, blir spørsmålet om det er statin som er årsaken. Man kan forsøke seg frem med perioder med og uten statin. Er plagene relatert til statinbehandlingen, må man vurdere om de kan skyldes en interaksjon med andre medikamenter eller om disponerende sykdom ligger til grunn. Deretter er det naturlig å 
redusere dose eller bytte statin. Atorvastatin og rosuvastatin har lange halveringstider og kan gis annenhver dag $(\underline{16})$. En lav dose statin kombinert med

kolesterolabsorpsjonshemmeren ezetimib gir like kraftig kolesterolsenkning som en høy dose statin alene (17.), men ezetimibbehandling er foreløpig ikke undersøkt i studier på harde endepunkter. Andre lipidsenkende legemidler som resiner kan også kombineres med statin i lav dose. Kostbehandling rettet mot reduksjon av mettet fett har stor betydning hos noen. Margarin tilsatt kolesterolsenkende plantesteroler reduserer LDLkolesterol med opp mot 10 \%, og vannløselige fiber fra havrekli og psyllium kan også redusere LDL-kolesterolet (묘). De fleste pasienter finner til slutt et behandlingsopplegg som tolereres.

\section{Konklusjon}

Statiner forebygger kardiovaskulær sykdom og $\mathrm{d} ø \mathrm{~d}$ og har vide behandlingsindikasjoner. Bivirkninger forekommer hos ca. 5 \%, i de fleste tilfeller uten påvisbare biokjemiske avvik.

\section{HOVEDBUDSKAP}

Statiner er vist å forebygge kardiovaskulær sykdom og død

For hver $1 \mathrm{mmol} / \mathrm{l}$ reduksjon i LDL-kolesterol synker risikoen for kardiovaskulær sykdom med $20 \%$

Behandlingsmål er ifølge europeiske retningslinjer avhengig av pasientens risiko

Bivirkninger er oftest muskulære eller gastrointestinale og kan være vanskelig å diagnostisere

\section{LITTERATUR}

1. Endo A. The origin of the statins. 2004. Atheroscler Suppl 2004; 5: 125-30. [PubMed] [CrossRef]

2. Norsk Reseptregister. www.reseptregisteret.no (30.4.2013).

3. Baigent C, Blackwell L, Emberson J et al. Efficacy and safety of more intensive lowering of LDL cholesterol: a meta-analysis of data from 170,000 participants in 26 randomised trials. Lancet 2010; 376: 1670-81. [PubMed] [CrossRef]

4. Reiner Z, Catapano AL, De Backer G et al. ESC/EAS Guidelines for the management of dyslipidaemias: the Task Force for the management of dyslipidaemias of the European Society of Cardiology (ESC) and the European Atherosclerosis Society (EAS). Eur Heart J 2011; 32: 1769-818. [PubMed] [CrossRef]

5. Helsedirektoratet. Risikokalkulator. http://rkalk.helsedir.no/default.aspx (30.4.2013).

6. Helsedirektoratet. Nasjonale retningslinjer for individuell primærforebygging av hjerte- og karsykdommer. Oslo: helsedirektoratet, 2009. www.helsedirektoratet.no/publikasjoner/nasjonalfaglig-retningslinje-for-individuell-primerforebygging-av-hjerte-og-karsykdommer/Publikasjoner/IS1550.pdf(30.4.2013).

7. Harada-Shiba M, Arai H, Oikawa S et al. Guidelines for the management of familial hypercholesterolemia. J Atheroscler Thromb 2012; 19: 1043-6o. [PubMed] [CrossRef]

8. Edwards JE, Moore RA. Statins in hypercholesterolaemia: a dose-specific meta-analysis of lipid changes in randomised, double blind trials. BMC Fam Pract 2003; 4: 18. [PubMed] [CrossRef]

9. U.S. Food and Drug Administration. FDA Drug Safety Communication: Ongoing safety review of high-dose Zocor (simvastatin) and increased risk of muscle injury. www.fda.gov/Drugs/DrugSafety/PostmarketDrugSafetyInformationforPatientsandProviders/ucm2048 82.htm\#SafetyAnnouncement (19.03.2010). 
10. Jones PH, Davidson MH, Stein EA et al. Comparison of the efficacy and safety of rosuvastatin versus atorvastatin, simvastatin, and pravastatin across doses (STELLAR* Trial). Am J Cardiol 2003; 92: 152-6o. [PubMed] [CrossRef]

11. Felleskatalogen. www.felleskatalogen.no (30.4.2013).

12. Armitage J. The safety of statins in clinical practice. Lancet 2007; 370: 1781-90. [PubMed] [CrossRef]

13. Thompson PD, Clarkson P, Karas RH. Statin-associated myopathy. JAMA 2003; 289:1681-90. [PubMed] [CrossRef]

14. Staffa JA, Chang J, Green L. Cerivastatin and reports of fatal rhabdomyolysis. N Engl J Med 2002; 346: 539-40. [PubMed] [CrossRef]

15. Sattar N, Preiss D, Murray HM et al. Statins and risk of incident diabetes: a collaborative metaanalysis of randomised statin trials. Lancet 2010; 375: 735-42. [PubMed] [CrossRef]

16. Juszczyk MA, Seip RL, Thompson PD. Decreasing LDL cholesterol and medication cost with everyother-day statin therapy. Prev Cardiol 2005; 8: 197-9. [PubMed] [CrossRef]

17. Pesaro AE, Serrano CV Jr, Fernandes JL et al. Pleiotropic effects of ezetimibe/simvastatin vs. high dose simvastatin. Int J Cardiol 2012; 158: 400-4. [PubMed] [CrossRef]

18. Pal S, Khossousi A, Binns $C$ et al. The effect of a fibre supplement compared to a healthy diet on body composition, lipids, glucose, insulin and other metabolic syndrome risk factors in overweight and obese individuals. Br J Nutr 2011; 105: 90-100. [PubMed] [CrossRef]

Publisert: 25. juni 2013. Tidsskr Nor Legeforen. DOI: 10.4045/tidsskr.12.0825

Mottatt 6.8. 2012, første revisjon innsendt 25.12. 2012, godkjent 30.4. 2013. Medisinsk redaktør Kristin Viste.

(C) Tidsskrift for Den norske legeforening 2023. Lastet ned fra tidsskriftet.no 26. april 2023. 